\title{
KOMUNIKASI PEMASARAN TERPADU MAKE OVER MELALUI BEAUTY VLOGGER DALAM MEMBANGUN CITRA MEREK
}

\author{
Farras Arafiah Zahra, Salman \\ Pragram Studi Ilmu Komunikasi Institut Teknologi dan Bisnis Kalbis \\ Email: farras2727@gmail.com, salman.naning@kalbis.ac.id
}

\begin{abstract}
This research was a case where researchers curiosity to know the use of integrated marketing komunuikasi using beauty vlogger role of sarah ayu in building brand product image makeover.This research use descriptive methods with techniques qualitative data collection of indepth interviews, and the study of literature. This research concluded that with integrated marketing communications by sarah ayu as beauty vlogger can build a brand image make overs become better with video shown by sarah ayu where in the video explains sarah ayu one by one the quality of the product that has been used in the video. With explanations of those products make the audience gave positive responses against brand make overs.Attitude with communication resulting from watching the video is brand image makeover namely positive image in view of the consumer.
\end{abstract}

Key words: beauty vlogger, brand image, integrated marketing communications, make over dan sarah ayu

\section{PENDAHULUAN}

Komunikasi Pemasaran terpadu adalah suatu konsep perencanaan komunikasi pemasaran yang mengakui nilai tambah dari satu rencana komprehensif yang mengevaluasi peran strategis dari berbagai disiplin komunikasi misalnya, iklan umum, respons langsung, promosi penjualan, dan hubungan masyarakat dan menggabungkan berbagai disiplin tersebut guna memberikan kejelasan, konsistensi, serta dampak komunikasi yang maksimal (Morissan, 2010:8). Dengan berbagai saluran komunikasi pemasaran terpadu seperti iklan, direct marketing, interactive/internet marketing, promosi penjualan, humas dan personal selling. Salah satunya yaitu interactive/internet marketing di mana dengan seiring perkembangan internet saat ini memungkinkan adanya arus informasi yang timbal balik. Internet saat ini sudah menjadi media iklan yang menarik (Morissan, 2010:24). Saat ini banyaknya promosi yang dilakukan dengan menggunakan internet sebagai media iklan atau mempromosikan suatu barang atau jasa kepada konsumen. Salah satu melakukan promosi melalui sebuah situs web atau media sosial YouTube.

YouTube adalah sebuah situs web berbagi video yang dibuat oleh tiga mantan karyawan paypal yaitu, Chad Hurley, Steve Chen dan Jawel Karim pada Februari 2005. Pada tanggal 14 Februari 2005 diaktifkan sebagai domain YouTube yaitu www.youtube.com, video pertama yang ditampilkan adalah video yang bejudul "me at he zoo" yang diunggah pada tanggal 23 April 2005 dan saat ini tayangan samapai dengan 23 jutaan kali. Pada bulan juli 2006, YouTube mulai meroket dengan mengumumkan bahwa lebih dari 65.000 video diunggah setiap harinya dan menerima 100 juta kunjungan video perhari (Rohman, 2017:4-5).

Di dalam YouTube terdapat berbagai macam jenis video yang diunggah setiap harinya salah satunya yaitu vlog. Di mana vlog merupakan sebuah blog berbentuk video. Blog merupakan bentuk situs pribadi yang berisi kumpulan tautan ke situs lain yang dianggap menarik dan diperbabarui setiap 
harinya, perkembangan selanjutnya blog banyak memuat jurnal (tulisan keseharian pribadi) si pemilik dan terdapat kolom komentar yang bisa diisi oleh pengunjung (Rulli Nasrullah, 2013: 34). Vlog merupakan video jurnalis yang berada di dalam web atau situs web yang berisikan mengenai kehidupan, pikiran, opini, dan ketertarikan. Di dalam vlog terdapat berbagai macam hal yang dibahas atau dibicarakan. Seperti salah satunya yaitu mengenai kecantikan, fashion, dan lainnya. Seseorang yang memiliki ketertarikan seputar kecantikan, skincare dan lainnya dan dengan suka rela membantu mereview terhadap sebuah produk perlengkapan kecantikan disebut beauty vlogger.

Seperti salah satu beauty vlogger Sarah Ayu merupakan wanita IndonesiaAmerika yang saat ini mulai terkenal dan sudah membuat akun YouTube sekitar tahun 2014. Dengan video pertama yang diunggah di Youtube pada Januari 2015 menjadi awal kariernya sebagai Beauty Vlogger. Dengan video pertamanya yang di-upload sekitar dua tahun lalu dengan penonton lebih dari 65.000 pada bulan Agustus 2017. Dengan terus berkarya di YouTube hingga saat ini Sarah Ayu sudah memilki subscriber sebanyak 160.000 pada bulan Agustus 2017 dan terus bertambah setiap harinya. Dengan banyaknya subscriber yang dimilikinya, Sarah Ayu diminta menjadi pembicara di beberapa event dan sudah membuat sebuah meet and greet serta beauty class yang diselenggarakan pada 10 September tahun lalu yang bertempat di Bandung. Di dalam channel YouTube Sarah Ayu sendiri sudah terdapat berbagai macam jenis video yang diuggah salah satunya video mengenai brand asal Indonesia dimana Sarah Ayu membuat sebuah video tutorial dan membuat Review mengenai produk tersebut. Video yang berjudul "One Brand Makeup Tutorial + Review// makeover" dengan durasi 22:52 menit mendapatkan jumlah penonton lebih dari 342.000 penonton dan 4.412 yang menyukai video tersebut. Pada video tersebut Sarah Ayu diberikan sebuah produk dari
Makeover dan video tersebut tidak disponsori oleh brand tersebut namun karena permintaan dari subscriber Sarah Ayu sehingga dia membuat sebuah video tersebut. Pada video tersebut Sarah Ayu memberikan tanggapan mengenai produk-produk dan memperlihatkan bagaimana cara menggunakan produk tersebut.

Pada penelitian ini fokus kepada salah satu beauty vlogger Sarah Ayu. Sarah Ayu termasuk kedalam salah satu dari keempat beauty vlogger lainnya. Beauty vlogger lainnya yaitu Abel Cantika, Stefany Talita dan Marcella Febrianne yang diundang ke luar negeri karena rajin membuat video tutorial di YouTube hal tersebut seperti yang diungkap di Tribun news Bogor (Ajeng, http://bogor.tribunnews.com/2017/03/24/beau ty-vlogger-ini-rajin-bikin-video-tutorial-

make-up-di-youtube-sampai-diundang-keluar-negeri?page=all, akses 20 Agustus 2017). Selain itu Sarah Ayu juga beberapa kali di undang di berbagai acara seperti salah satunya adalah Tips Menjadi Vlogger Viral Ala The Sibling Hunter. Mengutip Natalia (http://ultimagz.com/event/tips-jadi-vloggerviral-ala-the-hunter-siblings/, akses 20 Agustus 2017), pada kesempatan kali itu Sarah Ayu dengan kakanya yaitu Jovi Adhiguna diundang di event tersebut. Dua youtubers ternama, yaitu Jovi Adhiguna dan Sarah Ayu menjadi narasumber dalam acara Viralogy yang digelar pada Sabtu $(03 / 12 / 16)$ bertempat di Unity Ballroom 7th floor. Kedua youtubers yang lebih dikenal sebagai The Hunter Siblings tersebut diundang untuk membagikan tips menjadi viral kepada para peserta workshop. Viral sendiri berarti sesuatu yang sangat cepat menjadi populer di kalangan pengguna internet. Dalam workshop yang bertemakan "Everybody Goes To Viral" ini, Jovi Adhiguna dan Sarah Ayu membahas awal pembentukkan channel youtube milik mereka. Mereka menceritakan ketika pertama kali memulai untuk membuat channel youtube, mereka merasa tidak percaya diri dan juga merasa aneh. Namun karena seringnya 
berlatih, akhirnya mereka pun merasa nyaman dan terbiasa. Sarah mengungkapkan bahwa alasannya membuat channel youtube sendiri awalnya hanya sekadar untuk mengisi kebosanan. Namun, karena video yang ia buat mendapat respon yang sangat baik dari penonton, ia pun akhirnya memutuskan untuk menekuni bidang tersebut. Event lainnya seperti yang diselenggarakan pada bulan maret lalu Sarah Ayu turut hadir dalam acar tersebut yaitu Beauty Fest Asia 2017 dan dihadiri beberapa influencers laiinya (http://beautyfest.popbela.com/, akses 20 Agustus 2017) dengan begitu pada penelitian ini fokus kepada salah satu Beuaty Vlogger yaitu Sarah Ayu Hunter.

$$
\text { Banyaknya video yang telah }
$$
dihasilkan oleh Sarah Ayu seperti salah satunya yang berjudul "One Brand Makeup Tutorial + Review// makeover" di mana dalam video tersebut Sarah Ayu menggunakan produk Make Over. Merek Make Over adalah sebuah produk professional makeup PT. Paragon Technology and Innovation. Sejak muncul pada tahun 2010 Make Over telah memperlihatkan kemajuannya dengan memiliki beberapa penghargaan seperti mendapatkan penghargaan Women's Health Indonesia Choice 2013 untuk 4 kategori tersebut adalah pertama Make Over Liquid Lip Color terpilih sebagai Lipstik paling seksi pilihan editor, kategori kedua yaitu Make Over Lipbalm Lip Nutrition Orange Crush terpilih sebagai Pelembab bibir yang lembut \& segar, pilihan Pembaca, kategori ketiga yaitu Make Over Cheek Marbles terpilih sebagai Pemulas pipi yang terlihat natural, pilihan Pembaca dan yang terakhir yaitu Make Over Ultra Liquid Matt Foundation terpilih sebagai Alas bedak yang mudah menyatu dengan kulit, pilihan Pembaca. Make Over sudah membuka 120 outlet di Indonesia (http://www.pticosmetics.com/brands/make-over, akses 20 Februari 2017). Dengan banyaknya cabang yang dimiliki saat ini sehingga mulai banyak dikenali oleh masyarakat luas khususnya wanita yang menggunakan dan mencari makeup.

Dengan melalui komunikasi pemasaran terpadu oleh beauty vlogger dengan produk Make Over seperti pada video tersebut dapat membangun Brand Image di konsumen dengan tanggapan yang diberikan di beberapa videonya. Brand Image atau citra merek merepresentasikan keseluruhan persepsi dari merek dan dibentuk dari informasi dan pengalaman di masa lalu terhadap merek itu. Citra didefinisikan sebagai penjumlahan dari gambarangambaran, kesan-kesan dan keyakinankeyakinan yang dimiliki seseorang terhadap suatu objek (Abdullah, 2017:64). Pada saat sebuah citra merek telah dibangun dan mendapatkan citra positif dapat menguntungkan untuk terus mengembangkan produk tersebut agar dapat lebih memberikan dampak baik bagi kedepannya dan dapat terus diingat di benak konsumen. Dengan citra yang baik dapat membantu suatu brand atau produk terus menerus melakukan inovasi dan kreasi agar produknya dapat bertahan di pasar.

Dalam hal ini citra mewujudkan nilai yang besar dimana nilai suatu merek dapat dikuantifikasikan dalam bentuk uang, tetapi nilai yang sebenarnya di medan pasar yang kompetitif adalah kemampuan merek untuk merebut perhatian dan mempengaruhi pilihan (Temporal dan Lee, 2002:77). Dengan citra yang positif suatu brand atau produk dapat bersaing dan dapat merebut perhatian konsumen dengan mudahnya. Suatu citra yang melekap di dalam sebuah produk dapat menjadi suatu identitas terhadap produk tersebut. Brand image atau citra merek merupakan suatu identitas yang dipersepsikan oleh konsumen terhadap suatu merek tertentu. Dengan konsumen mengetahui persis mengenai suatu produk dan mempresepsikan suatu produk akan menimbulkan citra terhadap produk tersebut. Merek sendiri adalah "nama, istilah, symbol, desain, atau 
kombinasi semuanya yang dimaksudkan untuk mengidentifikasi barang atau jasa dari suatu penjual atau sekelompok penjual dan untuk membedakannya dari produk atau jasa kompetitor". Seperti pengertian merek menurut Direktorat Jendral Hak Kekayaan Intelektual (Dirjen HAKI) yakni: "suatu tanda yang berupa gambar,nama,kata huruf-huruf, angka-angka, susunan warna atau kombinasi dari unsur-unsur tersebut yang memiliki daya pembeda dan digunakan dalamm kegiatan perdagangan barang dan jasa" (Swasty, 2016:4). Dengan merek menjadi sebuah tanda atau simbol yang membedakan dengan produk sejenis merek menjadi suatu hal yang penting atau menjadi sebuah identitas yang membedakan dengan produk lainnya.

Pada penelitian ini, peneliti tertarik dengan sebuah citra dapat terbentuk bukan melalui media periklanan BTL (Below The Line) atau ATL (Above The Line) melainkan dengan cara menampilkan sebuah video dalam sebuah situs di media sosial YouTube dan dengan cara menampilkan produk untuk digunakan dalam video tersebut. Dalam hal ini pada video yang diunggah ke dalam sebuah media sosial YouTube oleh salah satu beauty vlogger Sarah Ayu, yang menampilkan sebuah produk dan menggunakannya serta membuat sebuah penilaian tentang produk yang berasal dari brand Make Over. Dalam hal ini peneliti ingin mengetahui bagaimana persepsi atau citra merek yang dapat oleh Make Over.

\section{METODOLOGI}

\section{A. Komunikasi Pemasaran Terpadu}

Asosiasi Biro Iklan Amerika berhasil menyusun definisi komunikasi pemasaran terpadu yang menjadi salah satu definisi pertama di bidang ini, yaitu: "A concept of marketing communication planning that recognizes the added value of $a$ comprehensive plan that evaluates the strategic roles of a variety of communication disciplines-for example, general advertising, direct response, sales promotion, and public relation and combines these discplines to provide clarity, consistency and maximum communication impact". Yang artinya adalah suatu konsep perencanaan komunikasi pemasaran yang mengakui nilai tambah dari satu rencana komprehensif yang mengevaluasi peran strategis dari berbagai disiplin komunikasi misalnya, iklan umum, respons langsung, promosi penjualan, dan hubungan masyarakat dan menggabungkan berbagai disiplin tersebut guna memberikan kejelasan, konsistensi, serta dampak komunikasi yang maksimal (Morissan, 2010:8).

Definisi tersebut memusatkan perhatiannya pada proses penggunaan seluruh bentuk promosi untuk mencapai dampak atau efek komunikasi yang maksimal. Komunikasi pemasaran terpadu merupakan upaya untuk menjadikan seluruh kegiatan pemasaran dan promosi perusahaan dapat menghasilkan citra atau image yang bersifat satu dan konsisten bagi konsumen. Komunikasi pemasaran terpadu atau integrated marketing communication (IMC). Kegiatan komunikasi pemasaran itu mencangkup : pemasangan iklan, pemasaran langsung, promosi penjualan, penjualan personal, pemasaran interaktif dan hubungan masyarakat. Tom Duncan dan Sandra Moriarty menyatakan bahwa IMC merrupakan pendekatan pemasaran "generasi baru" yang digunakan perusahaan untuk lebih memfokuskan upaya mereka dalam memperoleh, mempertahankan dan mengembangkan hubungan perusahaan dengan para pelanggan serta pihak-pihak terkait lainnya. Pada level komunikasi pemasaran, Duncan dan Moriarty mengatakan bahwa seluruh pesan harus disampaikan dan diterima secara konsisten dalam upaya untuk menciptakan persepsi yang utuh diantara pelanggan dan pihak terkait lainnya (Morissan, 2010:6-11). Dengan begitu komunikasi pemasaran terpadu adalah sebuah kegaitan komunikasi yang menggunakan berbagai macam kegiatan untuk melakukan 
pemasaran guna mendapatkan kegiatan pemasaran yang efektif.

\section{B. Promosi}

Michael Ray, mendefinisikan promosi sebagai "the coordination of all seller-iniated efforts to setup channel of information and persuasion to sell goods and services or promote an ide" yaitu koordinasi dari seluruh upaya yang dimulai pihak penjual untuk membangun berbagai saluran informasi dan persuasi untuk menjual barang dan jasa atau memperkenalkan suatu gagasan. Dalam hal ini instrument dasar yang digunakan untuk mencapai suatu tujuan komunikasi perusahaan disebut dengan bauran promosi atau promotional mix (Morissan, 2010:16-17). Jadi promosi adalah kegiatan yang dilakukan untuk memperkenalkan barang atau jasa kepada konsumen degan berbagai cara melalui saluran komunikasi dan dapat juga menggunakan bauran pemasaran. Bauran pemasaran atau promotional mix memiliki beberapa elemen sebagai yang dapat digunakan sebagai media promosi atau pemasaran.

Pada bauran promosi mencakup empat elemen, yaitu: iklan (advertising), promosi penjualan, publikasi/humas, dan personal selling. Namun George dan Michael Belch menambahkan dua elemen dalam promotional mix, yaitu direct marketing dan interactive media. Dua elemen yang terakhir pada saat ini telah banyak digunakan oleh pengelola pemasaran untuk berkomunikasi dengan khalayak. Pada pembahasan ini bauran pemasaran atau promotional mix yang akan di lihat dari interactivel internet marketing (Morissan, 2010:17).

Pada interactivel internet marketing atau pemasaran interaktif memulai perubahan dibidang teknologi komunikasi yang memungkinkan dilakukannya komunikasi secara interaktif melalui media massa, dalam hal ini yang utama adalah internet, khususnya melalui fasilitas yang dikenal dengan world wide web (www). Media interaktif memungkinkan terjadinya arus informasi timbal balik yang memungkinkan pengguna dapat berpartisipasi dan memodifikasi bentuk dan isi informasi pada saat itu juga. Kehadiran internet tidak saja telah mengubah cara-cara perusahaan dalam merancang dan melaksankan strategi bisnis dan pemasaran namun juga memperngaruhi program komunikasi pemasaran mereka. Internet saat ini sudah menjadi media iklan yang menarik. Banyak praktisi pemasaran mengiklankan produk mereka baik di web site sendiri maupun di web site milik perusahaan lain. Dapat dikatakan internet merupakan media yang bahkan dapat digunakan untuk melakukan kegiatan promosi bentuk lainnya, seperti promosi penjualan dengan kupon, kontes dan undian secara online. Praktisi pemasaran juga menggunakan Internet untuk melakukan pemasaran langsung, penjualan personal, serta kegiatan hubungan masyarakat secara lebih efektif dan efisien.

Selain berfungsi sebagai media promosi, internet juga dipandang sebagai suatu instrument komunikasi pemasaran yang bersifat mandiri. Karena sifatnya yang interaktif, internet menjadi cara yang efektif untuk berkomunikasi dengan konsumen atau khalayak. Pada saat sekarang ini banyak perusahaan yang mengakui keuntungan berkomunikasi melalui internet dan menyediakan anggaran khusus untuk mengembangkan web site mereka agar dapat menjadi bagian dari program komunikasi (Morissan, 2010:23-25).

\section{Citra Merek (Brand Image)}

Menurut American Marketing Association (AMA) merek adalah "nama, istilah, symbol, desain, atau kombinasi semuanya yang dimaksudkan untuk mengidentifikasi barang atau jasa dari suatu penjual atau sekelompok penjual dan untuk membedakannya dari produk atau jasa kompetitor". Seperti pengertian merek menurut Direktorat Jendral Hak Kekayaan Intelektual (Dirjen HAKI) yakni: "suatu tanda yang berupa gambar,nama,kata huruf-huruf, angka-angka, susunan warna atau kombinasi 
dari unsur-unsur tersebut yang memiliki daya pembeda dan digunakan dalamm kegiatan perdagangan barang dan jasa" (Swasty, 2016:4). Berdasarkan beberapa uraian dapat disimpulkan bahwa merek adalah penanda suatu produk atau jasa yang terdiri darin unsur visual (logo, maskot, kemasan) maupun unsur verbal (nama, tagline, jingle) yang membedakan dengan pesaing sejenis. Dengan begitu ketika sebuah merek sudah di tempatkan atau diberikan di sebuah produk merek tersebut menjadi suatu identitas yang digunakan untuk membedakan dari produk yang sejenis.

Citra adalah konsep yang mudah dimengerti, tetapi sulit dijelaskan secara sistematis karena sifatnya abstrak. Namun Rangkuti mengemukakan bahwa "citra merek adalah sekumpulan asosiasi merek yang terbentuk di benak konsumen". Dalam buku Perilaku Konsumen (2013: 327) menurut Aaker dalam Simamora, "citra merek adalah sperangkat asosiasi unik yang ingin diciptakan atau dipelihara oleh pemasar. Citra merek atau brand image dapat dianggap sebagai jenis asosiasi yang muncul di benak konsumen ketika mengingat sebuah merek tertentu. Menurut Aaker dalam Simamora, citra merek adalah seperangkat asosiasi unik yang ingin diciptakan atau dipelihara oleh pemasar. Aosiasi-asosiasi itu menyatakan apa sesungguhnya merek dan apa yang dijanjikan kepada konsumen. Merek merupakan simbol dan indikator dari kualitas sebuah produk. Oleh karena itu, merek-merek produk yang sudah lama akan menjadi sebuah citra, bahkan simbol status bagi produk tersebut yang mampu meningkatkan citra pemakainya. Asosiasi merek sendiri menurut Aaker dalam Simamora adalah sekumpulan entitas yang bisa dihubungkan dengan suatu merek. Asosiasi merupakan atribut yang ada di dalam merek dan akan lebih besar apabila pelanggan mempunyai banyak pengalaman berhubungan dengan merek tersebut. Shimp et al berpendapat mengenai citra merek (brand image ) yaitu, citra merek dapat dianggap sebagai jenis asosiasi yang muncul di benak konsumen ketika mengingat sebuah merek tertentu. Asosiasi tersebut secara sederhana dapat muncul dalam bentuk pemikiran atau citra tertentu yang dikaitkan dengan suatu merek, sama halnya ketika kita berpikir mengai orang lain. Dapat disimpulkan bahawa citra merek dapat positif atau negatif, tergantung pada persepsi seseorang terhadap merek. Ingatan terhadap sebuah merek dapat berupa atribut produk dan manfaat yang dirasakan oleh konsumen. Gambar berikut ini merupakan gambaran pengetahuan konsumen atas merek (Sangadji dan Sopiah, 2013:327328). Pada citra terdapat jenis-jenis asosiasi dan kekuatan terhadap merek dapat mempengaruhi citra merek (Sangadji dan Sopiah, 2013:328). Pada gambar di atas dapat dijelaskan sebagai berikut:

\section{Asosiasi merek}

Menurut Aaker "asosiasi merek adalah sekumpulan entitas yang bisa dihubungkan dengan suatu merek". Lebih lanjut, Aaker mendefiniskan asosiasi merek sebagai segala hal yang berkaitan dengan ingatan mengenai sebuah merek. Asosiasi merupakan atribut yang ada di dalam merek dan akan lebih besar apabila pelanggan mempunyai banyak pengalaman berhubungan dengan merek tersebut. Berbagai asosiasi yang diingat oleh konsumen dapat dirangkai sehingga membentuk citra merek (Sangadji dan Sopiah, 2013:328)

\section{Dukungan asosiasi merek}

Dukungan asosiasi merek merupakan respons konsumen terhadap atribut, manfaat serta keyakinan dari suatu merek produk berdasarkan penilaian mereka atas produk. Atribut di sini tidak berkaitan dengan fungsi produk, tetapi berkaitan dengan citra merek. Dukungan asosiasi merek tersebut ditunjukan dengan persepsi konsumen terhadap produk yang menganggap bahwa produk yang dikonsumsi itu baik dan bermanfaat bagi konsumen (Sangadji dan Sopiah, 2013:331). Jadi asosiasi merek adalah persepsi konsumen 
atau khalayak mengenai suatu produk atau merek yang berkaitan dengan produk tersebut.

\section{Kekuatan asosiasi merek}

Setelah mengetahui dan mengonsumsi sebuah produk konsumen akan mengingat kesan yang dihasilkan dari produk tersebut. Jika konsumen telah merasakan manfaatnya, ingatan konsumen terhadap produk tersebut akan lebih besar lagi dari pada ketika konsumen belum menggunakan produk tersebut. Itulah yang membuat ingatan konsumen semakin kuat terhadap asosiasi sebuah merek. Kekuatan asosiasi merek ditunjukan dengan reputasi baik yang dimiliki produk tersebut di mata konsumen, produk tersebut dirasa memiliki manfaat ekspresi diri dan menambah rasa diri konsumen (Sangadji dan Sopiah, 2013:331). Dalam kekuatan asosiasi merek dapat dipengaruhi dari pernah atau tidaknya konsumen mengongsumsi produk tersebut karena pada saat konsumen atau khalayak mengomsumsi produk tersebut dan merasakan manfaat saat itulah membuat ingatan konsumen terhadap produk atau brand tersebut.

\section{Keunikan asosiasi merek}

Jika sebuah produk mempunyai ciri khas yang membedakannya dari produk lain, produk tersebut akan diingat oleh konsumen. Ingatan konsumen itu akan semakin kuat jika konsumen sudah merasakan manfaat dari sebuah produk dan merasa bahwa merek lain tidak akan bisa memuaskan keingannya tersebut.

Rangkuti mendefinisikan citra merek sebagai sekumpulan asosiasi merek yang terbentuk di benak konsumen. Dengan kata lain, citra merek adalah seperangkat ingatan yang ada di benak konsumen mengenai sebuah merek, baik itu positif mapun negatif. Ingatan terhadap sebuah merek dapat berupaatribut produk dan manfaat yang dirasakan oleh konsumen. Menurut Kotler, atribut produk tidak berkaitan dengan fungsi produk, melainkan dengan citra sebuah produk di mata konsumen. Citra yang positif atau ngetif lebih mudah dikenal oleh konsumen sehingga produsen selalu berusaha mempertahankan, memperbaiki, dan meningkatkan citra merek produknya di mata konsumen. Citra merek yang positif memberikan manfaat bagi produsen untuk lebih dikenal konsumen.

\section{YouTube}

YouTube adalah sebuah situs web berbagi video yang dibuat oleh tiga mantan karyawan paypal yaitu, Chad Hurley, Steve Chen dan Jawel Karim pada Februari 2005. Menurut cerita yang beredar di media, Herley yang pernah belajar desain di Indiana University of Pennsylvania, sedangkagkan Chen dan Karim pernah belajar di University of Illinois at Urbana Champaign. Ide YouTube tercetus terjadi pada bulan-bulan pertama tahun 2005 dalam acara pesta makan malam di San Francisco. Awalnya YouTube adalah sebuah perusahaan teknologi rintisan yang didanai oleh investasi senilai $\$ 11,5$ juta dari Sequioa Capital antara bulan November dan April 2006. Pada waktu di kantor pertamanya terletak di atas sebuah pizzeria dan restoran jepang di San Mateo, Clifornia. Pada tanggal 14 Februari 2005 diaktifkan sebagai domain YouTube yaitu www.youtube.com, video pertama yang ditampilkan adalah video yang bejudul "me at he zoo" yang diunggah pada tanggal 23 April 2005 dan saat ini tayangan samapai dengan 23 jutaan kali. Pada bulan juli 2006, YouTube mulai meroket dengan mengumumkan bahwa lebih dari 65.000 video diunggah setiap harinya dan menerima 100 juta kunjungan video perhari. Dengan meroket tersebut YouTube mendapat masalah munculnya situs serupa yang bernama www.utube.com yang pemiliknya adalah Unversal Tube dan Rofllform Equipment dan pada waktu itu pemilik situs mengajukan tuntutan hokum terhadap YouTube pada bulan November 2006 dan sejak itu juga Universal Tube 
mengubah situsnya menjadi www.utubeonline.com (Rohman, 2017:4-5).

Pada bulan Oktober 2006, Goggle Inc, mengumumkan bahwa merek telah membeli YouTube dengan nilai \$i,65 miliar dalam bentuk saham. Dengan pengelolaan YouTube oleh Google Inc, memberikan kemajuan terhadap manajemennya sehingga pada tahun 2008 penghasilan YouTube mencapai \$200 juta. Dalam perkembangan YouTube melakukan beberapa kerjasama pemasaran dan periklanan dengan $\mathrm{NCB}<\mathrm{MGM}<$ Lion Gate Entertaiment, Fox dan Disney. Dimana mereka mengizinkan mengunggah/upload film yang disertai kotak iklan khusus yang diberi nama "Shows". Mulai pada bulan Maret 2010 YouTube mulai menyiarkan konten tertentu secara gratis seperti siaran olah raga dan meluncurkan desain baru yang bertujuan untuk menyerdahanakan antarmuka dan meningkatkan waktu penonton, sehingga pada bulai Mei YouTube melaporkan telah melayani lebih dari 2 miliar video perhari, selanjutnya pada bulan Mei 2011 menerima lebih dari 3 miliar kunjungan perhari dan bulan Januari 2012 jumlahnya naik menjadi 4 miliar perhari (Rohman, 2017:5-6).

\section{E. Paradigma dan Jenis Penelitian}

Paradigma sebagai "basic belief system or world view that guides the investigator, not only in choices of method but in ontologically and epistemologically fundamental ways" (paradigma adalah sistem keyakinan dasar atau cara memandang dunia yang membimbing peneliti, tidak hanya dalam pemilihan metode, tetapi juga cara-cara fundamental yang bersifat ontology dan epistomologis). Secara singkatnya "paradigma as basic belief system based on ontological, epistemological, and methodological assumptions" (paradigma merupakan sistem keyakinan dasar berdasarkan asumsi ontologis, epistemology dan metedologi) (Gunawan, 2103:48). Menurut Guba dalam buku metode penelitian kualitatif menyatakan but philosophers of science now uniformly belive that facts are facts only within some theoretical framework. Thus the basis for discovering "how things really are" and really work" is lost. "reality" exists only in the context of mental framework(construct) for thingking about it. (ahli-ahli filsafat ilmu pengetahuan percaya bahwa fakta hanya berada dalam kerangka kerja teori. Basis untuk menemukan "sesuatu benar-benar ada" dan "benar-benar bekerja" adalah tidak ada.Realitas hanya ada dalam konteks suatu kerangka kerja mental untuk berpikir tentang realitas tersebut).Ini berarti realitas itu ada konstruksi dari kemampuan berpikir seseorang. Beberapa hal lagi dijelaskan tentang kontruktivisme oleh Guba ialah: finally, it depicts knowledge as the outcome or consequence of human activity: knowledge is a human construction, never certifiable as ultimately true but problematic and ever changing. (penghetahuan dapat digambarkan sebagai hasil atau konsekuensi dari aktivitas manusia, pengetahuan merupakan konstruksi manusia, tidak pernah dipertanggunmgjawabkan sebagai kebenaran yang tetap tetapi merupakan permasalahan dan selalu berubah). Artinya, bahwa aktivitas manusia itu merupakan aktivitas mengonstruksi realitas, dan hasilnya tidak merupakan kebenaran yang tetap, tetapi selalu berkembang terus.Berdasarkan beberapa penjelasan Guba yang dikutip di atas, dapat disimpulkan bahwa realitas itu merupakan hasil kontruksi manusia (Gunawan, 2013:4850). Paradigma penelitian ini menggunakan paradigma konstruktivis.Dimana paradigma konstruktivis merupakan salah satu prespektif dalam tradisi sosiokultural.Paradigma ini menyatakan bahwa identitas benda dihasilkan dari bagaimana kita berbicara tentang objek, bahasa yang digunakan untuk mengungkap konsep dan cara-cara kelompok sosial menyesuaikan diri pada pengalaman umum mereka. Keberadaan simbol atau bahasa menjadi penting dalam proses pembentukan realitas. Berbagai kelompok dengan identitas, pemaknaan, kepentingan, pengalaman, dan sebagainya mencoba mengungkapkan diri dan 
selanjutnya akan memberi sumbangan dalam membentuk realitas secara simbolik. Realitas secara simbolik merupakan hasil kesepakatan bersama secara sosial. Realitas tidak menunjukkan dirinya dalam bentuknya yang kasar, tetapi harus disaring terlebih dahulu melalui bagaimana cara kita atau seseorang melihat sesuatu (Stephen dan Foss, 2011:67).

Dari penjabaran tersebut, maka penelitian ini dilakukan dengan menggunakan jenis penelitian kualitatif. Penelitian ini menggunakan pendekatan kualitatif karena Penelitian adalah proses yang digunakan untuk mengumpulkan dan mengalisis informasi guna meningkatkan pemahaman kita pada suatau topik. Terdapat tiga pentingnya melalukan penelitian yaitu: penelitian menambah pengetahuan, penelitian meningkatkan praktik dan penelitian menginformasikan perdebatan kebijakan. Pada penelitian ini menggunakan metode penelitian kualitatif di mana penelitian kualitatif dimaksud sebagai jenis penelitian yang temuan-temuanya tidak diperoleh melalui prosedur statistic atau bentuk hitungan lainnya.Metode kualitatif lebih berdasarkan pada sifat fenomologis yang mengutamakan penghayatan.Metode kualitatif berusaha memahami dan menafsirkan makna suatu peristiwa interaksi tingkah laku manusia terkadang perspektif berdasarkan peneliti sendiri.Penelitian yang menggunakan penelitian kualitatif bertujuan untuk memahami objek yang diteliti secara mendalam.Informan dalam metode kualitatif berkembang terus secara bertujuan sampai data yang dikumpulkan dianggap memuaskan atau jenuh. Penelitian dengan pendekatan kualitatif menekankan analisis proses dari proses berpikir secara induktif yang berkaitan dengan dinamika hubungan antarfenomena yang diamati, dan senantiasa menggunakan dukungan logika ilmiah. Penelitian kualitatif bertujuan mengembangkan konsep sensitivitas pada masalah yang dihadapi, menerangkan realitas yang berkaitan dengan penelusuran teori dari bawah dan mengembangkan pemahaman akan satu atau lebih dari fenomena yang dihadapi. Penelitian kualitatif menurut flick dalam buku Penelitian Kualitatif adalah specific relevan to the study of social relations, owing to the fact the pluralization of life worlds.Penelitian kualitatif adalah keterkaitan spesifik pada studi hubungan sosial yang berhubungan dengan fakta dari pluralisasi dunia kehidupan. Metode ini diterapkan untuk melihat dan memahami subjek dan objek penelitian yang meliputi orang, lembaga berdasarkan fakta yang tampil secara apa adanya. Melalui pendekatan ini akan terungkap gambaran mengenai aktualisasi, realitas sosial dan presepsi sasaran penelitian (Gunawan, 2013:79-81). Melalui pendekatan kualitatif dalam penelitian ini menggunakan jenis penelitian yaitu deskriptif karena ingin mendeskripsikan mengenai komunikasi pemasaran terpadu melalui Beauty Vlogger Sarah Ayu dalam membangun citra merek Make Over melalui video di YouTube. Jenis penelitian deskriptif ini bertujuan membuat deskripsi secara sistematis,factual dan akurat tentang fakta-fakta dan sifat-sifat populasi atau objek tertentu. Periset sudah mempunyai konsep dan kerangka konseptual. Melalui kerangka konseptual, periset melakukan operasionalisasi konsep yang akan menghasilkan variabel beserta operasionalnya. Riset ini untuk menggambarkanrealitas yang sedang terjadi tanpa menjelaskan hubungan antarvariabel (Kriyantono, 2010: 69).

\section{F. Teknik Pengumpulan Data}

Dalam penelitian ini, peneliti memperoleh data melalui data primer dan data sekunder. Data primer pada penelitian yakni ini menggunakan wawancara dimana pengertian wawancara adalah suatu percakapan yang diarahkan pada suatu masalah tertentu dan meruapakan proses tanya jawab lisan dimana dua orang atau lebih berhadapan sacara fisik. Wawancara dilakukan untuk memperoleh data atau infomasi sebanyak mungkin dan sejelas mungkin kepada subjek penelitian. 
Wawancara merupakan bentuk pengumpulan data yang paling sering bercakap-cakap dengan orang untuk mendapatkan informasi penting. Wawancara pada penelitian kualitatif memiliki sedikit perbedaan dibandingkan dengan wawancara lainnya.Wawancara pada penelitian kualitatif merupakan pembicaraan yang mempunyai tujuan dan didahului beberapa pertayaan informal. Wawancara penelitian ditunjukan untuk mendapatkan informasi dari satu sisi saja sehingga hubungan asimetris harus tampak.Penelitian cenderung mengarahkan wawancara pada penemuan pesaan, persepsi dan pemikiran informan. Dalam melakukan wawnacra terdapat dengan dua cara yaitu wawancara terstruktur dan tidak terstrukstur. Dalam wawancara terstruktur digunakan karena informasi yang akan diperlukan peneliti sudah pasti. Wawancara tidak terstruktur bersifat lebih luwes dan terbuka. Wawancara tidak terstruktur dalam pelaksanaaanya lebih bebas dibandingkan dengan wawancara terstruktur karena dalam melakukan wawancara dilakukan secara alamiah untuk menggali ide dan gagasan informan secara terbuka dan tidak menggunakan pedoman wawancara (Gunawan, 2013:160-163). Data sekunder yaitu dengan studi literatur yang digunakan oleh peneliti diperoleh melalui buku-buku mengenai Komunikasi Pemasaran Terpadu, Media Baru dan buku penunjang lainnya. Selain itu, peneliti juga menggunakan buku penelitian kualitatif, skripsi, jurnal, dan website resmi serta media online resmi lainnya yang berkaitan dengan penelitian. Serta di tambahakan dengan dokumentasi. Menurut Gottschalk dalam Gunawan (2013:175) dokumentasi terdapat dua pengertian, yaitu pertama, berarti sumber tertulis bagi inromasi sejarah sebagai kebalikan dari pada kesaksian lisan, artefak, peninggalan-penginggalan terlukis dan petilasan-petilasan arkeologis. Pengertian kedua diperuntukan bagi surat-surat resmi dan surat-surat negara, seperti surat perjanjian, undang-undangan, hubah, konsesi dan lainnya. Gottschalk menyatakan lebih lanjut bahwa dokumentasi dalam pengertiannya yang lebih luas berupa setiap proses pembuktian yang didasarkan atas jenis sumber apapun, baik itu yang bersifat tulisan, lisan, gambaran atau arkeologis. Dokumentasi yang digunakan peneliti adalah sebuah video Sarah Ayu yang berjudul One Brand Makeup Tutorial + Review// makeover".

\section{G. Teknik Analisis Data}

Analisis data adalah proses mencari dan menyusun data yang diperoleh melalui wawancara, catatan lapangan dan dokumentasi dengan cara ingin menggolokan kedalam beberapa pola memilih mana yang penting yang akan dipelajari dan dibuat kesimpulannya. Teknik Analisis yang digunakan dalam penelitian ini adalah analisis data Interaktif Miles dan Huberman memiliki teknik analisis yang terdiri dari tiga komponen yaitu: reduksi data (data reduction), penyajian data (data display), dan penarikan serta pengujian kesimpulan (drawing and verifying conclusions). Langkah reduksi data melibatkan beberapa tahap.Tahap pertama, melibatkan langkah-langkah editing, pengelompokan, dan meringkas data.Pada tahap kedua, peneliti-menyusun kode-kode dan catatan-catatan (memo) mengenai berbagai hal, termasuk yang berkenaan dengan aktivitas serta proses-proses sehingga peneliti dapat menemukan tema-tema, kelompok-kelompok, dan pola-pola data.Catatan yang dimaksdukan di sini adalah gagasan-gagasan atau ungkapan-ungkapan yang mengarah pada teorisasi data atau gejala tertentu dapat dibuat sepanjang satu kalimat atau mungkin beberapa paragraf. Pada tahap terakhir dari reduksi data, peneliti menyusun rancangan konsep-konsep serta penjelasanpenjelasan berkenaan dengan tema, pola, atau kelompok-kelompok data yang bersangkutan (Pawito, 2007:104-105)

\section{PEMBAHASAN}

Pembahasan penelitian ini di analisis dengan penggunaan komunikasi pemasaran terpadu melalui Beauty Vlogger Sarah Ayu 
dalam membangun citra merek Make Over. Citra merek tesebut di hasilkan melalui video yang berjudul "One Brand Makeup Tutorial + Review// makeover".

\section{A. Komunikasi Pemasaran Terpadu melalui Bauty Vlogger}

Komunikasi Pemasaran Terpadu adalah suatu konsep perencanaan komunikasi pemasaran yang mengakui nilai tambah dari satu rencana komprehensif yang mengevaluasi peran strategis dari berbagai disiplin komunikasi misalnya, iklan umum, respons langsung, promosi penjualan, dan hubungan masyarakat dan menggabungkan berbagai disiplin tersebut guna memberikan kejelasan, konsistensi, serta dampak komunikasi yang maksimal. Komunikasi pemasaran terpadu atau integrated marketing communication (IMC). Kegiatan komunikasi pemasaran itu mencangkup: pemasangan iklan, pemasaran langsung, promosi penjualan, penjualan personal, pemasaran interaktif dan hubungan masyarakat. Dengan menggunakan salah satu kegiatan komunikasi pemasaran terpadu yaitu interactive/ internet marketing atau pemasaran interaktif dapat menambah informasi seputar produk-produk Make Over dan dapat juga mengetahui kualitas produknya. Melalui video tersebut Sarah Ayu sebagai Beauty Vlogger dalam hal ini juga mempromosikan produknya kepada konsumennya dengan cara menggunakan produknya dan juga menjelaskan mengenai produk tersebut. Jadi dapat dikatakan bahwa dengan menggunakan komunikasi pemasaran terpadu dapat membantu dalam memberikan informasi dan juga memperkenalkan produk Make Over kepada konsumen.

\section{B. Pengetahuan Akan Merek}

Sebuah merek sangatlah penting, karena dapat menjadi salah satu identitas yang membedakan dengan produk lainnya. Dengan begitu merek menjadi salah satu indentitas dari sebuah jasa atau barang yang dapat membedakan dengan lainnya. merek tersendiri memeiliki beberapa manfaat seperti bagi pembeli, bagi masyarakat dan bagi penjual. Dalam hal pengetahuan akan merek konsumen atau penonton video yang berjudul "One Brand Makeup Tutorial + Review// makeover" sudah mengetahui tentang merek tersebut dan mengetahui beberapa produk yang terdapat di pada merek MakeOver.

\section{Kesadaran Akan Merek}

Pada tahap sadar akan produk Make Over atau brand awareness konsumen atau khalayak sudah sadar akan brand Make Over. Seperti halnya komponen pengenalan akan merek peneliti sudah menemukan bahwa konsumen atau khalayak sudah mengenal merek. Dengan sudah mengetahui akan merek MakeOver yang merupakan salah satu komponen yang mendasari kesadaran akan merek sudah ada di dalam benak konsumen. Setelah adanya pengenalan akan merek selanjutnya komponen yang kedua yaitu kemampuan untuk mengingat merek. Pada komponen ini konsumen dapat mengingat akan merek tersebut dan terdapat dibenak tentang merek tersebut. Dalam hal mengingat sebuah merek dapat berasal dari produknya atau persepsi konsumen atau khalayal tentang merek tersebut. Pada komponen kedua yaitu mengingat sebuah merek, brand Make Over sudah mendapatkannya yaitu di mana konsumen atau khalayk sudah mengingat brand tersebut dan yang terdapat dibenak konsumen mengenai brand tersebut adalah brand lokal tapi memiliki kualitas yang bagus dan tidak kalah dengan produk yang berasal dari luar negri dengan packaging

Dengan begitu kesadaran akan merek atau pengetahuan merek Make Over dibenak konsumen sudah ada dan tinggi karena sudah menjadi top of mind dibenak mereka tentang merek tersebut. Kesadaran akan merek atau brand awareness dapat membantu proses dimana brand image atau citra merek karena dalam hal ini konsumen sudah sadar akan suatu merek dan didukung dengan pengetahuan akan merek tersebut dapat 
menjadikannya proses presepsi muncul secara subjek dengan berbagai pengalaman dan pemaknaan yang diketahui. Sehingga seseorang dengan adanya pengetahuan akan merek dan sadar akan suatu merek dapat membantu untuk membangun sebuah citra merek dengan bantuan persepsi mengenai suatu hal dan pengalaman yang terjadi. Setelah pengetahuan akan merek sudah terdapat di dalam benak konsumen selanjutnya unsur yang masuk kedalam brand image atau citra merek Make Over yang dibangun melalui video di jejaring media sosial YouTube oleh Sarah Ayu.

\section{Citra Merek MakeOver}

Komponen yang terdapat dalam citra merek atau brand image jenis-jenis asosiasi merek, dan dukungan, kekuatan dan keunikan asosiasi merek. Dengan berbagai kompenon dalam citra menghasilkan sebuah citra merek yang menjadi suatu identitas atau segala asosiasi yang membedakan dengan produk lainnya. Melalui video yang terdapat di YouTube berjudul "“'One Brand Makeup Tutorial + Review// makeover" menghasilkan sebuah citra merek di benak konsumen dilihat dari berbagai komponen yang mendasari citra merek.

\section{- Asosiasi merek}

Aaker mendefiniskan asosiasi merek sebagai segala hal yang berkaitan dengan ingatan mengenai sebuah merek. Asosiasi merek yang dimiliki Make Over sudah terdapat di benak konsumen dimana asosiasi merek yaitu hal berkaitan dengan merek tersebut seperti produknya atau dapat berupa logo dari merek tersebut. Hal yang berkaitan dengan merek tersebut sudah diketahui oleh konsumen dengan megetahui logo Make Over yaitu bertuliskan Make Over dengan packaging hitam dan tidak hanya itu saja di dalam asosiasi merek konsumen sudah mengetahui beberapa produk Make Over. jadi dapat dikatakan bahwa asosiasi merek sudah ada dibenak konsumennya.

- Dukungan asosiasi merek
Dukungan asosiasi merek adalah persepsi konsumen atau khalayak mengenai suatu produk atau merek yang berkaitan dengan produk tersebut. Setelah menonton video Sarah Ayu yang berjudul "One Brand makeup Tutorial+ Review // Makeover" konsumen mengetahui manfaat yang didapat mengenai produk tersebut. Persepsi yang muncul setelah menonton video tersebut adalah terdapat beberapa produk MakeOver yang memang bagus karena dalam riview yang diberikan oleh Sarah Ayu benar-benar jujur bila produk tersebut bagus dia akan mengatakannya melaikan sebaliknya.

- Kekuatan asosiasi merek

Pada kekuatan asosiasi merek akan lebih bertambah ketika konsumen telah merasakan manfaat dari produk tersebut. Dalam hal ini narasumber hanya sebatas mencoba produknya dan belum mengkonsumsinya terus menurus namun dari hanya mencoba menggunakannya narasumber langsung menyukai produk tersebut. Dapat dikatakan bahwa kekuatan asosiasi merek dapat juga terbentuk dengan melihat video yang dilakukan oleh Sarah Ayu di YouTube di tambah dengan mencoba produk tersebut kekuatan asosiasi merek dapat terbentuk. Jadi kekuatan asosiasi merek dapat terbentuk dengan adanya informasi dan pengetahuan langsung produk tersebut dapat menambah kekuatan asosiasi merek atau persepsi akan merek tersebut.

- Keunikan asosiasi merek

Keunikan yang dimiliki sebuah merek dapat menambah daya ingat konsumen akan sebuah merek. Seperti halnya MakeOver dimana melalui video Sarah Ayu dapat diketahui bahwa yang membedakan MakeOver dengan merek lainnya adalah salah satu produknya yang bisa hampir sama dengan produk lainnya dan packagingnya yang berwarna hitam sudah menjadi ciri khas dari produknya. Melalui video tersebut dapat diketahui bahwa MakeOver memiliki keunikan yaitu dari segi packaging yang serba 
hitam yang memberikan kesan elegan dan tidak hanya itu saja di di dalam video tersebut dapat diketahui keunikan lainnya dimana salah satu produknya memiliki kemiripan dengan produk lain hal tersebut menurut konsumen atau penonton video Sarah Ayu menjadi salah satu keunikan tersendiri. Dengan adanya ciri khas yang membedakan merek MakeOver dengan lainnya dapat memudahkan konsumen mengingat akan merek tersebut dan ketika ingatan konsumen menjadi kuat dapat melalui dengan cara konsumen tersebut mengkonsumsi atau mengetahui manfaat langsung dari produk tersebut. merek sudah dikenal dan kethaui oleh konsumennya. Dari seluruh komponen citra merek dapat dikatakan citra merek Make Over baik yaitu sebagai merek lokal yang memiliki kualitas yang bagus dan didukung dengan packaging yang serba hitam dan dapat menghasilkan kesan elegan. Citra tersebut dapat dibangun dengan menonton video Sarah Ayu di mana pengetahuan akan merek dan produk menjadi bertambah serta kualitas yang dimiliki oleh Make Over dan dengan video yang dihasilkan oleh Beauty Vlogger Sarah Ayu di YouTube menambah pengetahuan seputar kualitas dan cara mengaplikasikan produk Make Over.

\section{KESIMPULAN}

Dari penelitian yang dilakuakan ini dengan teknik pengumpulan data yaitu wawancara mendalam oleh penonton sekaligus pengikut channel YouTube Sarah Ayu dalam sebuah video berjudul One Brand makeup Tutorial + Review MakeOver. Dalam video tersebut dilihat bahwa ketika Sarah Ayu meriview atau menjelaskan produk MakeOver dapat diketahui bahwa terdapat beberapa produk yang memang terbukti kualitasnya dan beberapa produk yang kurang bagus namun secara keseluruhan produk tersebut memiliki kualitas yang bagus. Dapat diketahui melalui komunikasi pemasaran terpadu yang dilakukan oleh Beauty Vlogger Sarah Ayu sebagai dapat membangun citra merek (brand image) MakeOver menjadi baik dilihat dari riviewnya yang menjelaskan secara informatif di mana penonton dapat mengetahui lebih jelas mengenai manfaat serta kegunaan dari produk tersebut dan tidak hanya itu saja dengan komunikasi pemasaran terpadu yang dilakukan dapat memperkenalkan produknya kepada konsumen dengan inofrmasi yang diberikan oleh Sarah Ayu sehingga konsumen mengetahui produk serta kualitas yang ada didalam produk tersebut.

MakeOver yang awalnya hanya dikenal dengan beberapa produknya saja dengan video Sarah Ayu dapat mengenalkan lebih luas lagi beberapa produk serta dapat memberikan pengetahuan lebih bahwa MakeOver adalah produk yang berasal dari Indonesia namun memilki kualitas yang tidak kalahnya dengan produk yang berada diluaran sana. Tidak sebatas hanya itu saja namun saat ini MakeOver sudah mendapatkan ciri khas tersendiri dengan packagingnya yang hitam dan simpel yang membuat kesan elengan sudah menjadi salah satu identitas yang membedakan dengan produk lain. Dapat dikatakan bahwa dengan adanya pengetahuan seputar merek MakeOver dan dengan adanya video mengenai MakeOver di YouTube Sarah Ayu menambah pengetahuan dan informasi mengenai MakeOver.

Sebagai Beauty Vlogger Sarah Ayu dapat dikatakan berhasil membangun brand image MakeOver dalam video tersebut karena tanggapan konsumen atau penonton video tersebut mengenai brand MakeOver memberikan tanggapan positif seputar merek MakeOver. Jadi dapat dikatakan bahwa saat ini di media digital promosi dapat dilakukan dengan berbagai cara. Seperti halnya penggunaan Beauty Vlogger menjadi salah satu media promosi dan dapat juga membangun brand image. Sama halnya dengan MakeOver dengan video yang berada di YouTube oleh salah satu Beauty Vlogger dapat membangun citra merek MakeOver dan lebih memperkenalkan merek tersebut kepada khalayak luas. 


\section{DAFTAR PUSTAKA}

Abdullah M. M. (2017). Manajemen Komunikasi periklanan. Yogyakarta: Aswaja Pressindo

Gunawan, I. (2013). Metode Penelitian Kualitatif: Teori \& Praktek. Jakarta: PT Bumi Aksara.

Kriyantono, R. (2010). Teknik Praktis Riset Komunikasi. Jakarta: Kencana.

Littlejohn, S. dan Foss (2011). Teori Komunikasi. Jakarta: Salemba Humanika.

Morissan. (2010). Periklanan: Komunikasi Pemasaran Terpadu. Jakarta: Kencana.

Nasrullah. R. (2013). CYBER MEDIA. CYBER MEDIA. Yogyakarta: IDEA Press Yogyakarta.

Pawito. (2007). Penelitian Komunikasi Kualitatif. Yogyakarta: PT LKiS Pelangi Aksara

Rohman. A. (2017). YouTube For Profit: Mendapatkan Uang Cash dan Terkenal dengan Membuat Channel YouTube Sendiri Secara Gratis. Jakarta: Jasakom

Sangadji, E.M., dan Sopiah. (2013). Prilaku Konsumen: Pendekatan Praktis Disertai:Himpunan Jurnal Penelitian. Yogyakarta: Penerbit Andi.

Swasty. W. (2016). Branding: Memahami dan Merancang Strategi Merek. Bandung: PT Remaja Rosdakarya.

Temporal. P. dan Lee. (2002). HI TECH HI TOUCH BRANDING. Jakarta: PT Salemba Embat
Paragon Technology and Innovation [online] 20 Februari 2017. dari http://www.pticosmetics.com/brands/make-over 